\title{
28 Research Soure \\ Calvarial Metastasis of Lung Cancer: a Case Report and Literature Review
}

Hao Xing

PUMCH https://orcid.org/0000-0002-9100-9590

Shishuai Wang

PUMCH: Peking Union Medical College Hospital

Xiaopeng Guo

PUMCH: Peking Union Medical College Hospital

Penghao Liu

PUMCH: Peking Union Medical College Hospital

\section{Yuekun Wang}

PUMCH: Peking Union Medical College Hospital

\section{Yaning Wang}

PUMCH: Peking Union Medical College Hospital

\section{Binghao Zhao}

PUMCH: Peking Union Medical College Hospital

\section{Yu Wang ( $\nabla$ ywang@pumch.cn )}

PUMCH: Peking Union Medical College Hospital https://orcid.org/0000-0002-7175-4649

Wenbin Ma

PUMCH: Peking Union Medical College Hospital

\section{Case report}

Keywords: lung cancer, calvarial metastasis, operation, epidural effusion

Posted Date: May 12th, 2021

DOI: https://doi.org/10.21203/rs.3.rs-499259/v1

License: 두 (i) This work is licensed under a Creative Commons Attribution 4.0 International License. Read Full License 


\section{Abstract}

Background: The skull is an uncommon site for bone metastasis of lung cancer. The most common type of skull metastasis is calvarial circumscribed intraosseous lesions. However, the use of targeted therapy or surgery remains controversial and the prognosis is poor.

Case presentation: Skull metastasis was detected in a woman 4 years after resection of non-small cell lung cancer. Despite targeted drug therapy, the tumor continued to grow. However, the patient refused surgical treatment until she developed neurological deficit. An epidural effusion occurred after the operation. The patient was followed up for 16 months and her condition remained stable.

Conclusion: Skull metastases of lung cancer can grow invasively. The current and previously reported cases highlight the importance of prompt removal of tumors located in the calvaria.

\section{Background}

About $10 \%$ of patients with lung cancer develop bone metastasis, usually in the spine, but about $3 \%$ of patients with bone metastasis of lung cancer have skull metastasis ${ }^{[1]}$. The most common type of skull metastasis of lung cancer is calvarial circumscribed intraosseous lesions, followed by calvarial diffuse invasive lesions ${ }^{[2]}$. Localized intraosseous tumors often show progressive growth. Sometimes, even large tumors do not invade the brain parenchyma and the patient may have no neurological damage ${ }^{[3]}$. However, the patient may develop neurological dysfunction if the tumor infiltrates the parenchyma. Clinical treatment usually involves biopsy to confirm the pathological diagnosis, followed by radiochemotherapy and/or targeted therapy; however, the prognosis is extremely poor. This study summarizes the management of a patient with a giant skull metastasis of lung cancer, and provides a clinical reference for this condition.

\section{Case Presentation}

A 66-year-old woman was diagnosed with non-small cell lung cancer in September 2013. Gene detection disclosed an epidermal growth factor (EGFR) E19p.L747_T751del gene mutation. A right temporoparietal bone mass was found in August 2017, and magnetic resonance imaging (MRI) suggested a possible metastasis from her lung cancer (Fig. 1A). The patient refused surgery and started treatment with the EGFR inhibitor afatinib $30 \mathrm{mg}$ once daily. MRI 1 year later showed expansion of the lesion (Fig. 1B). The tumor increased progressively, accompanied by pain, dizziness, blurred vision of the right eye, swelling of the right face, and decreased muscle strength of the left arm and leg (grade IV) in July 2019, MRI showed extensive involvement of the subcutaneous tissue, muscle, skull, dura mater, and brain, to a maximum diameter of about $11 \mathrm{~cm}$ (Fig. 1C). The patient then opted for surgical treatment. A preoperative three-dimensional computed tomography scan showed that the lesion involved the frontal, temporal, parietal, and orbital bones (Fig. 1D). In the operation, we could not mill the bone flap and remove the tumor as in a normal craniotomy, and finally removed the bony part of the tumor using a milling cutter, ultrasonic knife, and other tools, and then excised the tumor from the brain, involving a time-consuming procedure with bleeding. Postoperative pathology and immunohistochemical staining showed a metastatic lung adenocarcinoma, with the following characteristics: ALK-D5F3(-), SATB2(-), CK20(-), CK7(-), Napsin A(+), p40(-), p63(-), TTF-1(-), ALK-D5F3(NC)(-), CDX-2(-), estrogen receptor(-), and progesterone receptor(-). Postoperative MRI showed that the tumor had been completely removed (Fig. 1E). However, the patient developed severe epidural effusion (Fig. 1F) and scalp infection 1 month after surgery. She then received radiotherapy combined with oxitinib after infection control. The patient died at 16 months after surgery.

\section{Discussion}


The available literature on skull metastasis of lung cancer was retrieved from PubMed. A total of eight reports were extracted from the database, and the initial clinical symptoms, position of metastasis, histology, therapy, and outcome are summarized in Table 1.

Table 1

Characteristics of cases of lung cancer with skull metastasis

\begin{tabular}{|c|c|c|c|c|c|c|c|}
\hline author, & age/sex & $\begin{array}{l}\text { initial } \\
\text { clinical } \\
\text { symptom }\end{array}$ & $\begin{array}{l}\text { position of } \\
\text { metastasis }\end{array}$ & $\begin{array}{l}\text { cranial } \\
\text { nerves } \\
\text { implicated }\end{array}$ & histology & therapy & outcome \\
\hline \multirow[t]{2}{*}{$\begin{array}{l}\text { Mengoli } \\
\text { MC, et al }\end{array}$} & \multirow[t]{2}{*}{$55 y / F$} & \multirow[t]{2}{*}{$\begin{array}{l}\text { skull } \\
\text { mass }\end{array}$} & \multirow{2}{*}{$\begin{array}{l}\text { Frontal } \\
\text { bone } \\
\text { Parietal } \\
\text { bone }\end{array}$} & \multirow[t]{2}{*}{-} & \multirow[t]{2}{*}{ adenocarcinoma } & \multirow[t]{2}{*}{ erlotinib } & \multirow{2}{*}{$\begin{array}{l}8 \text { months } \\
\text { Stable }\end{array}$} \\
\hline & & & & & & & \\
\hline $\begin{array}{l}\text { Zelenak } \\
\text { M,et al }\end{array}$ & $59 y / F$ & $\begin{array}{l}\text { acute } \\
\text { cavernous } \\
\text { sinus } \\
\text { syndrome }\end{array}$ & $\begin{array}{l}\text { sphenoid } \\
\text { bone }\end{array}$ & $\begin{array}{l}\text { II, III, IV, V, } \\
\text { VI, VIII }\end{array}$ & $\begin{array}{l}\text { non-small cell } \\
\text { lung cancer }\end{array}$ & $\begin{array}{l}\text { high-dose } \\
\text { steroids + } \\
\text { radiotherapy }\end{array}$ & $\begin{array}{l}2 \text { weeks } \\
\text { Progression }\end{array}$ \\
\hline $\begin{array}{l}\text { Djeric D, } \\
\text { et al }\end{array}$ & $73 y / F$ & $\begin{array}{l}\text { facial } \\
\text { palsy }\end{array}$ & $\begin{array}{l}\text { temporal } \\
\text { bone }\end{array}$ & VII & adenocarcinoma & - & $\begin{array}{l}\text { died } \\
\text { suddenly }\end{array}$ \\
\hline \multirow[t]{2}{*}{$\begin{array}{l}\text { Bakhos D, } \\
\text { et al }\end{array}$} & $76 y / M$ & $\begin{array}{l}\text { hearing } \\
\text { loss }\end{array}$ & $\begin{array}{l}\text { temporal } \\
\text { bone }\end{array}$ & VIII & adenocarcinoma & $\begin{array}{l}\text { carboplatin + } \\
\text { taxotere + } \\
\text { radiotherapy }\end{array}$ & $\begin{array}{l}5 \text { months } \\
\text { died }\end{array}$ \\
\hline & $74 y / M$ & $\begin{array}{l}\text { hearing } \\
\text { loss }\end{array}$ & $\begin{array}{l}\text { temporal } \\
\text { bone }\end{array}$ & VIII & $\begin{array}{l}\text { squamous cell } \\
\text { carcinoma }\end{array}$ & $\begin{array}{l}\text { carboplatin + } \\
\text { taxotere + } \\
\text { radiotherapy }\end{array}$ & $\begin{array}{l}3.5 \text { months } \\
\text { died }\end{array}$ \\
\hline $\begin{array}{l}\text { Moriyama } \\
\text { Y, et al }\end{array}$ & $61 \mathrm{y} / \mathrm{F}$ & $\begin{array}{l}\text { Garcin } \\
\text { Syndrome }\end{array}$ & $\begin{array}{l}\text { posterior } \\
\text { cranial } \\
\text { fossa }\end{array}$ & $I X, X, X I, X I I$ & $\begin{array}{l}\text { small cell lung } \\
\text { cancer, }\end{array}$ & $\begin{array}{l}\text { carboplatin + } \\
\text { etoposide }\end{array}$ & $\begin{array}{l}24 \text { months } \\
\text { stable }\end{array}$ \\
\hline $\begin{array}{l}\text { Fukai S, } \\
\text { et al }\end{array}$ & $76 y / F$ & $\begin{array}{l}\text { Garcin } \\
\text { Syndrome }\end{array}$ & $\begin{array}{l}\text { sphenoid } \\
\text { bone }\end{array}$ & IV, V, VI & $\begin{array}{l}\text { non-small cell } \\
\text { lung cancer }\end{array}$ & $\begin{array}{l}\text { Surgery + } \\
\text { Radiotherapy } \\
\text { + zoledronic } \\
\text { acid }\end{array}$ & $\begin{array}{l}5 \text { months } \\
\text { died }\end{array}$ \\
\hline $\begin{array}{l}\text { Moeller } \\
\text { JJ,et al }\end{array}$ & $58 y / F$ & $\begin{array}{l}\text { dysarthria } \\
\text { and } \\
\text { tongue } \\
\text { weakness }\end{array}$ & $\begin{array}{l}\text { occipital } \\
\text { condyle }\end{array}$ & XII & $\begin{array}{l}\text { small cell lung } \\
\text { cancer, }\end{array}$ & radiotherapy & $\begin{array}{l}5 \text { months } \\
\text { died }\end{array}$ \\
\hline $\begin{array}{l}\text { Takeuchi } \\
\text { S, et al }\end{array}$ & $64 y / M$ & $\begin{array}{l}\text { dysarthria } \\
\text { and } \\
\text { headache }\end{array}$ & $\begin{array}{l}\text { occipital } \\
\text { condyle }\end{array}$ & XII & adenocarcinoma & $\begin{array}{l}\text { radiotherapy } \\
+ \\
\text { chemotherapy }\end{array}$ & $\begin{array}{l}9 \text { months } \\
\text { died }\end{array}$ \\
\hline
\end{tabular}

The clinical manifestations of tumor metastases differ depending on their location. Localized intraosseous tumors often appear as progressively growing skull masses. These can sometimes be very large but do not invade the dura mater and brain, in which case the patient may have no neurological damage, except for changes in appearance. In the current case, however, the tumor showed diffuse invasive growth, and the patient had "mass effect" and neurological dysfunction. If the tumor involves the skull base, most cranial nerves can be involved, resulting in paralysis ${ }^{[4-10]}$. Tumors of the middle and posterior fossa involve more nerves, and patients can show different syndromes, such as acute cavernous sinus syndrome, Garxin syndrome, and occipital condylar syndrome. Notably, not all patients have a history of lung cancer followed by metastatic symptoms; the metastatic symptoms may sometimes occur first, while the primary lung cancer is only detected after further examination ${ }^{[9,11]}$. 
Most patients with skull metastasis of lung cancer have a very poor prognosis, especially when the tumor invades the skull base and cannot be removed by surgery. Even different radiotherapy and chemotherapy schemes may not result in an ideal response, and patients often die within months of their diagnosis, or are at risk of sudden death ${ }^{[5]}$. The current patient initially refused surgical treatment because of the surgical risk. However, subsequent extensive infiltration made surgery more difficult, with the huge tumor penetrating the subcutaneous tissue, muscle, skull, and dura mater, and being deeply rooted in the brain. Full resection should therefore be performed as early as possible in patients with craniofacial metastases, followed by radiochemotherapy. However, progress in targeted therapy means that increasing numbers of drugs are becoming available to improve patient survival.

Serious complications may occur during treatment. A previous report ${ }^{[12]}$ found that invasive skull metastases caused severe intracranial hemorrhage 3 weeks after radiotherapy and chemotherapy, eventually leading to death. Although the authors could not conclusively determine if the tumor had transferred from the skull to the brain, because of technical limitations, they concluded that this was likely. This scenario was further supported by our current case. Initial imaging showed that the tumor was limited to the skull and epidural space, but subsequently grew and infiltrated into the surrounding soft tissues, dura mater, and brain parenchyma. This case provides good imaging evidence for the infiltrating growth process of skull metastases in lung cancer. Although our patient did not develop a fatal intracerebral hemorrhage, postoperative epidural effusion and infection posed serious life-threatening complications. During the operation, we removed the tumor infiltrating the subcutaneous tissue, muscle, skull, and dura mater and repaired it with an artificial dura. Cranioplasty was not carried out because of the need for radiotherapy. There is a potential space between the artificial dura and subcutaneous tissue, which provides the anatomical basis of epidural effusion. The current patient developed a scalp infection with an unknown cause 1 month after surgery. Before the infection, the patient had multiple subcutaneous effusions to relieve the tension of the epidural effusion, which might have caused the infection. Attention should thus be paid to the potential complications of epidural effusion.

\section{Conclusion}

Skull metastases of lung cancer can grow invasively. The current and previous cases highlight the importance of early surgical removal of tumors located in the calvaria, while patients may also benefit from postoperative radiotherapy, chemotherapy, and targeted therapy.

\section{List Of Abbreviations}

EGFR epidermal growth factor

MRI magnetic resonance imaging

\section{Declarations}

\section{Ethics approval and consent to participate}

Ethics approval was not required for case reports deemed not to constitute research at our institution. The authors declare that the patient has given written consent for data and image collection.

\section{Consent for publication}

The authors declare that the patient has given written consent for publication.

\section{Availability of data and materials}


Data sharing not applicable to this article as no datasets were generated or analyzed during the current study.

\section{Competing interests}

The authors declare no competing interests.

\section{Funding}

Beijing Municipal Natural Science Foundation.

\section{Authors' contributions}

The authors declare to have agreed both to be personally accountable for author's own contributions and to ensure that question related to the accuracy or integrity of any part of the work, even once in which the author was not personally involved, are appropriately investigated, resolved, and resolution documented in the literature.

\section{Acknowledgements}

We thank Susan Furness, PhD, from Liwen Bianji, Edanz Editing China (www.liwenbianji.cn/ac), for editing the English text of a draft of this manuscript.

\section{References}

1. Sugiura H, Yamada K, Sugiura T, et al. Predictors of Survival in Patients With Bone Metastasis of Lung Cancer[J]. Clinical Orthopaedics \& Related Research,2008,466(3):729-736.

2. Mitsuya K, Nakasu Y, Horiguchi S, et al. Metastatic skull tumors: MRI features and a new conventional classification[J]. Journal of Neuro Oncology,2011,104(1):239-245.

3. Mengoli M C, Rossi G, Tiseo M, et al. 'Turban-like' skull metastasis from pulmonary adenocarcinoma[J]. Thorax,2017,72(8):767.

4. Zelenak M, Doval M, Gorscak J J, et al. Acute Cavernous Sinus Syndrome from Metastasis of Lung Cancer to Sphenoid Bone[J]. Case Reports in Oncology,2012,5(1):35-42.

5. Djeric D, Boricic I, Tomanovic N, et al. The facial palsy as first symptom of the temporal bone lung cancer metastasis[J]. Brazilian Journal of Otorhinolaryngology,2015,83(6):1067-1070.

6. Bakhos D, Chenebaux M, Lescanne $E$, et al. Two cases of temporal bone metastases as presenting sign of lung cancer[J]. European Annals of Otorhinolaryngology, Head and Neck Diseases,2012,129(1):54-57.

7. Yusuke, Moriyama, Keisuke, et al. A Case of Small Cell Lung Cancer with Garcin Syndrome[J]. Haigan,2013.

8. Moeller J J, Sudeep S, Mary D, et al. Occipital condyle syndrome as the first sign of metastatic cancer.[J]. Canadian Journal of Neurological Sciences,2007,34(4):456-459.

9. Takeuchi S, Osada H, Nagatani K, et al. Occipital condyle syndrome as the first sign of skull metastasis from lung cancer[J]. Asian J Neurosurg,2017,12(1):145-146.

10. Fukai S, Okabe N, Mine H, et al. Garcin syndrome caused by sphenoid bone metastasis of lung cancer: a case study[J]. World Journal of Surgical Oncology,2018,16(1):46.

11. Ryan, C, Turner, et al. Lung cancer metastasis presenting as a solitary skull mass.[J]. Journal of Surgical Case Reports,2016.

12. Hiraki $A$, Tabata $M$, Ueoka $H$, et al. Direct intracerebral invasion from skull metastasis of large cell lung cancer.[J]. Internal Medicine,1997,36(10):720. 


\section{Figures}

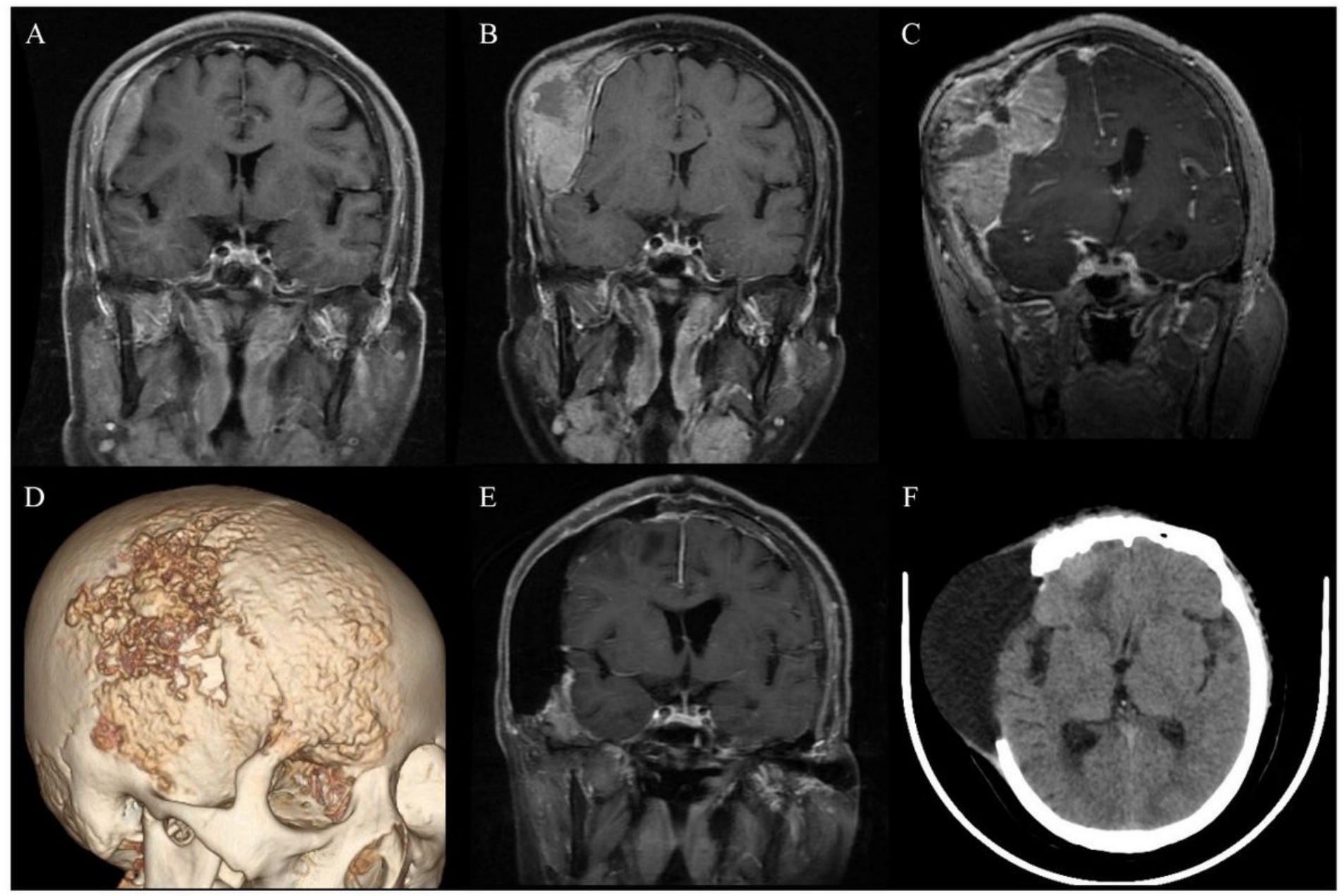

\section{Figure 1}

A) magnetic resonance imaging (MRI) suggested a possible metastasis from her lung cancer. B) expansion of the lesion.

C) MRI showed extensive involvement of the subcutaneous tissue, muscle, skull, dura mater, and brain. D) 3D-CT showed the lesion involved the frontal, temporal, parietal, and orbital bones. E) Post-operation MRI. F) epidural effusion. 